Article

\title{
Following Politicians on Social Media: Effects for Political Information, Peer Communication, and Youth Engagement
}

\author{
Franziska Marquart *, Jakob Ohme and Judith Möller \\ Amsterdam School of Communication Research, University of Amsterdam, 1018XE Amsterdam, The Netherlands; \\ E-Mails: f.marquart@uva.nl (F.M.), j.ohme@uva.nl (J.O.), j.e.moller1@uva.nl (J.M.) \\ * Corresponding author
}

Submitted: 10 January 2019 | Accepted: 16 March 2020 | Published: 19 May 2020

\begin{abstract}
Young citizens increasingly turn to social media platforms for political information. These platforms enable direct communication between politicians and citizens, circumventing the influence of traditional news outlets. We still know little about the consequences of direct contact with politicians on such platforms for citizens' political participation. Here, we argue that the interplay of different actors in the political news diet of citizens should be investigated from a networked communication perspective. Relying on a cross-sectional survey of young Danes (15-25 years old, $n=567$ ), we investigate the relationship between following politicians on social media and: (a) the composition of young citizens' political media diet; and (b) their civic messaging and campaign participation. Following political actors on social media relates to increased campaign engagement and can be a catalyst for young people's exposure to campaign news, but their friends and followers function as the main node of their political online networks. We document a process of the de-mediation of politics on social media: Established news media lose influence as primary information sources for young citizens. We discuss these results in the context of users' active curation and passive selection of their political social media diet.
\end{abstract}

\section{Keywords}

campaign engagement; Denmark; networked communication; political actors; social media use; youth participation

\section{Issue}

This article is part of the issue "Youth Digital Participation: Opportunities, Challenges, Contexts, and What's at Stake" edited by Neta Kligler-Vilenchik (Hebrew University of Jerusalem, Israel) and Ioana Literat (Teachers College, Columbia University, USA).

(C) 2020 by the authors; licensee Cogitatio (Lisbon, Portugal). This article is licensed under a Creative Commons Attribution 4.0 International License (CC BY).

\section{Introduction}

Young people increasingly turn to social media platforms for news and political information: $50 \%$ of citizens between 18-24 years use Facebook, YouTube, Instagram, Twitter, and Snapchat to access and discuss news in different countries (Reuters, 2019). In 2017, 75\% of Danes between 18-29 years report getting news daily from social media, and 61\% of 20-29 year old Danes discuss politics on Facebook with strangers (Matsa, Silver, Shearer, \& Walker, 2018; Rossi, Schwartz, \& Mahnke, 2016). During an election campaign, first-time Danish voters see campaign news on more than one third of campaign days and thereby significantly more often than older citizens (Ohme, 2019). This suggests that how younger generations seek out and consume political information is changing with the shifting modern media environment and growing relevance of social media platforms. News organizations still play a key role in this information environment; however, citizens also 'follow' and 'like' politicians' or parties' social media representation and receive regular status updates on events, policy announcements, or personal news (e.g., Manning, Pennfold-Mounce, Loader, Vromen, \& Xenos, 2017). Hence, a key aspect of social media is that it enables direct communication between politicians and citizens, allowing political actors to circumvent traditional news outlets (Parmelee \& Roman, 2019; Weeks, Kim, 
Hahn, Diehl, \& Kwak, 2019). This form of presentation resonates particularly well with younger citizens, who value politicians who are able to show themselves as 'one of us' - that is, a 'regular' person in contrast to the 'official' political persona (Manning et al., 2017). In line with this, more than one fifth of 18-24-year-old Danish citizens report following a political party on social media, and $17 \%$ follow at least one politician (Reuters, 2019; see also Fisher, Culloty, Lee, \& Park, 2019).

While a growing body of research investigates politicians' strategies on social media (e.g., Kreiss, Lawrence, \& McGregor, 2018; Stier, Bleier, Lietz, \& Strohmaier, 2018), the effects on citizen's political participation of following political actors online are understudied (but see Weeks et al., 2019). Furthermore, we lack insights into the effects of young people's engagement with politicians on social media. Late adolescence is a crucial time for the development of political and civil interests (e.g., Literat, Kligler-Vilenchik, Brough, \& Blum-Ross, 2018), while youths' online peer networks are a determining source of political socialization (Lee, Shah, \& McLeod, 2013). Therefore, the interplay of different actors in young people's political news diet must be investigated from a networked communication perspective to understand the impact of information acquisition on social media for political participation.

We use an original cross-sectional survey study conducted around the 2017 Danish municipality elections. Young citizens (15-25 years old, $n=567$ ) were questioned about their social media use and political engagement during an ongoing get-out-the-vote campaign. We take into account a number of relevant predictors established by prior research (e.g., interpersonal communication, general media use, political interest) to determine the effects of following politicians on social media on: (a) the composition of young citizens' political media diet; and (b) their civic messaging and campaign participation. We discuss our results in light of the influence of algorithmic selection and filtering processes (e.g., Thorson, Cotter, Medeiros, \& Pak, 2019; Thorson \& Wells, 2016) that affect how much political information young people are exposed to on social media. While our analyses rely on cross-sectional data, our findings provide valuable insights into the role that political actors play in the political information environment of the youth.

\section{Digital Participation as Part of the Political Socialization Process}

How young adults engage with politicians through social media may have a lasting influence on their relationship with politics. Theoretical as well as empirical work in the field of political socialization demonstrates that many civic attitudes and behaviors are primarily developed as young adults become eligible to vote (Valentino \& Sears, 1998), and during the period following this first formal exercise of citizenship, the so-called formative years (Mannheim, 1928/1952); it also results from young citizens perceiving the political world as remote and unresponsive to them (Loader, 2007). Hence, political interest is still developing during late adolescence and early adulthood (e.g., Fisher et al., 2019), and the impact of news and current affairs information is particularly pronounced during those years (Moeller, de Vreese, Esser, \& Kunz, 2014).

At the same time, the development of civic attitudes and behaviors goes hand in hand with young citizens' general identity formation: How they orient themselves towards the political world is likely to have a lasting impact on their later lives. Gerber, Green, and Shachar (2003) find, for example, that turnout for earlier elections is significantly associated with electoral participation in later stages of life. This orientation towards politics mostly takes place in the digital sphere (Literat et al., 2018). Online, young citizens can make use of their digital skills and realize their aims through communication practices familiar to them. Research demonstrates that online civic communication mediates political information processing (Lee at al., 2013), and functions as a steppingstone towards offline participation (Moeller et al., 2014). One core mechanism in this process is the development of internal political efficacy (e.g., Maurissen, 2018), or the perception of being competent "to understand and to participate effectively in politics" (Craig, Niemi, \& Silver, 1990, p. 290). By engaging with politics in the digital realm, adolescents gain confidence in their civic skills, which later translates into more political participation (Moeller et al., 2014). In this process, communication with politicians on social media may play a decisive role to bridge the gap between the seemingly abstract political world and the reality of adolescent life. Through engagement with politicians and politics online, adolescents can also foster perceptions of external efficacy or feeling heard. In an extensive review of the Civic Web research project that studied political participation of young citizens, Banaji and Buckingham (2010) find that politicians' meaningful engagement with adolescents in the context of peer-to-peer communication raises both adolescents' confidence in the responsiveness of the political system and their motivation to express their citizenship. The authors conclude that many characteristics of online communication, such as interactivity and openness, can empower young citizens to participate. This perspective regards young people as active agents in their own political socialization (Bennett, 2008). Social media facilitate this active role by allowing active curation and passive, algorithmic selections: Political information is not something that happens only in the news, but can be shared, forwarded, commented on, or remixed (Coleman, 2008).

\section{Following Politicians on Social Media}

Early research into the connection between political actors and citizens on social media finds only weak indicators for direct political communication, with limited 


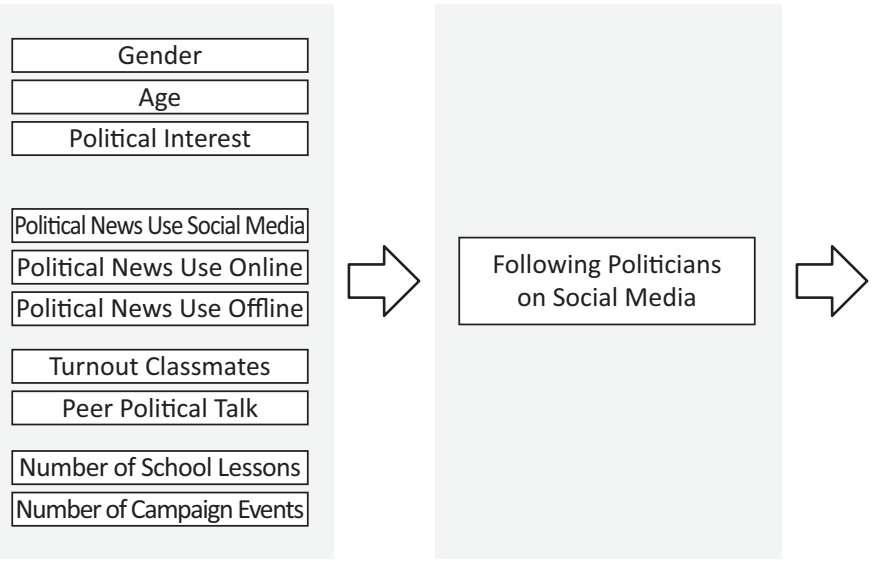

Figure 1. Conceptual model.

numbers of followers for a few prominent political candidates (Nielsen \& Vaccari, 2013). This context has changed drastically. In March 2020, 74 million users follow U.S. president Donald Trump's Twitter account. Through their representation within the open and free environment of social media, politicians can engage directly with their prospective electorate and bypass journalistic gatekeeping (e.g., Kreiss et al., 2018; Parmelee \& Roman, 2019; Sahly, Shao, \& Kwon, 2019). The potential consequences for citizens in general and adolescents in particular are manifold. We explore three important questions here (see Figure 1): (1) Who are the young followers of politicians on social media?; (2) in what way is the news diet of young voters determined by a mix of active curation and passive selection?; and (3) how does exposure to different sources of political content on social media relate to political behavior?

Relying on Reuters data, Fisher et al. (2019) find that politicians' followers are significantly younger than the average citizen, they prefer to "hear directly from a politician/political party [rather] than have their views filtered by others" (Fisher et al., 2019, p. 243). Social media have been associated with the hope that less political interested and resourceful citizens will engage with politics more frequently on these platforms compared to traditional media (Shehata \& Strömbäck, 2018). Yet, what personal traits and characteristics those young people who subscribe to politicians on social media have is an open question. We therefore ask:

\section{RQ1: Who follows politicians on social media?}

\subsection{Following Politicians and Algorithmic Content Selection}

On social media, politicians can post status updates, images, and videos, inform about policy positions, comment on current events, or advertise campaign events, which helps them to present themselves in a favorable way. It can be especially effective if it enables interaction with citizens who do not themselves follow politicians or parties, but are exposed to the content through their net-

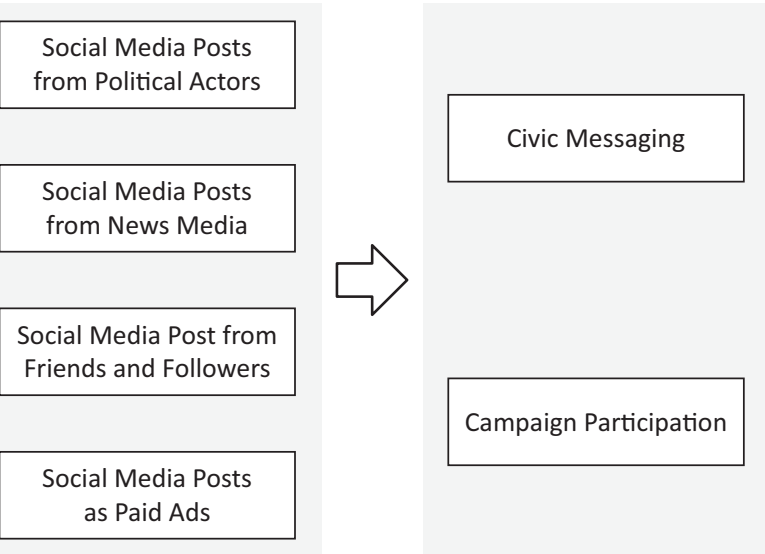

works' likes and recommendations (e.g., Karlsen, 2015; Nielsen \& Vaccari, 2013). An active digital followership is initially important for politicians on social media; however "how far each message spreads in the networks of their friends and followers depends on the algorithm" (Keller \& Kleinen-von Königslöw, 2018, p. 8).

Prior research shows that young citizens attend to different types of political social media posts to different extents. Ohme (2019) finds that, during the 2015 Danish national election campaign, first-time voters encounter posts from political actors more often than from the news media, friends and followers, or in the form of political advertisements. There is therefore variation in the source of political posts young citizens attend to, and political social media diets are not uniform. We ask whether exposure to the different sources of political content are affected by (the amount of) political actors young citizens actively select into their social media environment. Such curation affects the social media algorithm-possibly, individuals encounter related (political) information more frequently and at the expense of other content. This may be particularly pronounced when we assume that peer networks influence each other reciprocally: Through one's similarity with friends' political content preferences, political information is further prioritized in the news feed (see also Kaiser, Keller, \& Kleinen-von Königslöw, 2018). However, whether or not this is the case remains an empirical question. Hence, while following politicians is an active act of content curation, algorithmic content selection and the social relevance of those messages encountered determine how often users are exposed to information from politicians (see Messing \& Westwood, 2014; Thorson \& Wells, 2016). Although the exact function of algorithmic selection is less clear, the choice to include a political actor in one's social media diet is likely to affect one's digital trace data. Accordingly, "individual behavior, motivated by personal interest, shapes how the algorithm categorizes the interests of each user over time" (Thorson et al., 2019, p. 11). To determine what role the decision to follow a politician plays here, we ask: 
RQ2: Does following politicians relate to different sources of political posts young citizens encounter on social media during an election campaign?

\subsection{Following Politicians and Campaign Mobilization}

Politicians use social network sites to create a personalized communication style, distancing themselves from their respective parties and the traditional media (Geber \& Scherer, 2015; Kreiss et al., 2018). Mobilization is an important goal of this form of presentation, as is the spread of campaign-relevant information (Stier et al., 2018). Political candidates who emphasize social media over traditional methods of campaigning report direct communication with voters and higher visibility as imperative goals (Skovsgaard \& van Dalen, 2013). Enli and Rosenberg (2018) find that citizens' levels of trust in Norwegian politicians are higher when the politicians appear on social media, which might be ascribed to politicians being able to present a (seemingly) honest version of their story, unmediated by journalistic intervention. Getting to know political candidates and their issue positions through social media may help youth socialization processes as well. Young citizens demand politicians be likeable and approachable, but also responsible and trustworthy (Manning et al., 2017). Social media provide an advantageous environment for presenting these qualities and can be particularly helpful in connecting the youth with political leaders (Enli \& Skogerb $\varnothing$, 2013). At the same time, issue discussions on social media platforms remain the exception rather than the rule (van Dalen, Fazekas, Klemmensen, \& Hansen, 2015), and Keller and Kleinen-von Königslöw (2018) argue that political actors do not take the deliberative potential of social media platforms seriously enough.

Investigations into the effects of engagement with, and exposure to, politicians' profiles for citizens remain scarce, with notable exceptions. Studies demonstrate that politicians' communication on social media can affect perceptions of a political actor's authenticity (Enli \& Rosenberg, 2018; Kreiss et al., 2018) and audience engagement (e.g., Sahly et al., 2019). Kristensen et al. (2017) find that voting intention can be linked to citizens 'liking' the representations of politicians on social media. The effects of direct political communication on information exposure and political participation, especially among young citizens, however, remain unstudied, which is noteworthy given the role of social media in young people's lives.

Social media can play a pivotal role for youth mobilization during an election campaign. We differentiate two different types of engagement with the campaign, beyond following the news: Civic messaging and campaign participation (e.g., Kahne, Lee, \& Feezell, 2013). Research finds that, especially during their first election campaigns, young citizens are less certain about how to form a vote decision and rely more on information from the media (Aalberg \& Jenssen, 2007). Yet it is im- portant to not only be exposed to election news, but to engage with it. A recent study finds that the effects of social media use on first-time voters' vote choice certainty are fully mediated through campaign participation (Ohme, de Vreese, \& Albæk, 2018). Hence, while the use of news during campaigns is a first step to making an informed vote decision, commenting on or discussing politics online (i.e., through civic messaging) or attending political events and getting in touch with political actors (i.e., via campaign participation) can further aid information processing and help to develop an informed vote choice. Ultimately, being certain about what to vote for may be necessary to believing that turning out is efficacious (Sanders, 2001). It is therefore of interest, first, to what extent receiving politicians' messages in their social media diet increases young citizens' campaign engagement. Second, it is possible that including politicians in one's news diet alters how political messages from other sources relate to campaign engagement. Here, both a reinforcement role and an attenuating role of following politicians are possible. Reinforcement takes place through message consistency, for example, when posts from politicians and news media cover the same issue, or when friends and followers post information about a politician that the user follows. Message consistency can strengthen the political self (e.g., Wicks \& Drew, 1991) and thereby contribute to young citizens' campaign engagement. In turn, inconsistency between a politician's issue and messages from other sources in a newsfeed may increase uncertainty for young voters, which negatively relates to their level of campaign engagement (Ohme et al., 2018). Lastly, political information stemming from young people's personal networks and political actors are especially influential in contributing to citizens' campaign engagement, compared to posts from news media (Ohme, 2019). Therefore, we expect:

H1: Following political actors on social media positively relates to young citizens' level of civic messaging and campaign participation.

Formally, we ask whether the number of political actors young Danes follow on social media relates to their civic messaging and campaign participation through heightened encounters with political content from different sources. We therefore test a mediation model to unravel a potential algorithmic curation impact and ask:

RQ3: Do political posts from different sources that young citizens encounter on social media mediate the relationship between following politicians and their level of civic messaging and campaign participation?

\section{Method}

The data for this survey were collected in the fall of 2017 as part of a two-wave panel study fielded shortly before and after the Danish municipality elections (see also 
Ohme, Marquart, \& Kristensen, 2019). The data were collected on the Danish island Funen; the participants were 567 young Danish citizens ( $51 \%$ male). Participants for the panel were recruited via their teachers in 16 general and vocational upper secondary educational institutions if their classes participated in the non-partisan get-out-the-vote campaign STEM'RNE (The Voices). The initiative brought together local news organizations on Funen who collaborated with schools and the main university to increase youth turnout in the county to above $80 \%$ for the local elections. The campaign organized events and roundtable discussions and engaged young citizens via several social media networks; teachers in participating classes also dedicated a number of additional school lessons to the elections and political topics. Teachers encouraged their pupils to take part in this survey study, and provided them with the link to the online questionnaire (coordinated by KantarGallup); therefore, students with a highly engaged teacher were more likely to participate. The first wave of the survey ( $n=807$ ) was conducted before the start of the campaign in October 2017. The second wave collected data from 580 respondents; not all of these had participated in the first wave, and 279 could be matched to Wave 1 (W1) respondents by means of anonymized identifiers. The drop-out rate between W1 and Wave 2 (W2) was therefore quite high. Comparisons of sample descriptives from both waves show similar distributions with regard to age (W1: $M=18.88$; $W 2: M=18.64$ ), gender (W1: $50.2 \%$ female; W2: $48.6 \%$ female), origin (born in Denmark W1: 94.4\%; W2: 95.3\%), and political interest (W1: $M=6.57$; $\mathrm{W} 2: M=7.06$; range $1=$ not at all interested, to $7=$ very interested; see also Ohme et al., 2019). We rely on respondents from the second wave only, since it includes the relevant measures of campaign exposure, participation, and civic messaging, and exclude respondents who were above 25 years old; this results in our final sample size of $n=567$.

Our main independent variable asked respondents whether they 'followed any Danish politicians or political parties on a social media platform' (i.e., Facebook, Instagram, Snapchat, or Twitter). About half of the sample did not follow any politician or party $(53.1 \%) ; 29.6 \%$ followed one or two political actors, $9.9 \%$ followed three to five, and $7.7 \%$ followed more than five. The variable was recoded into a scale ranging from zero to three $(M=.72 ; S D=.92)$. To determine whether following politicians relates to the amount of election-related information received on social media, we asked participants how often, in the weeks before the municipality election, they saw 'posts from parties, politicians, political organizations and political actors' about politics and the election on social media platforms $(M=2.94$, $S D=.99 ; 1-$ never to 4-daily). They also indicated how often they encountered such posts by 'the news media' (e.g., Politiken; $M=3.14, S D=.93$ ), by 'friends or followers' $(M=2.35, S D=.95)$, and as 'paid advertisements' from parties and political actors $(M=2.78, S D=1.02)$.
For our first dependent variable, 'civic messaging,' we assessed how frequently (1-never to 4-daily) participants engaged in six activities (e.g., posted something about politics or the elections; discussed a political or election-related issue publicly online with others; chatted with friends/acquaintances about politics or the elections; see, e.g., Moeller et al., 2014). The six items form a reliable combined scale $(\alpha=.82)$; however, since we are interested in the joint impact of the six activities, we recoded them for a range of zero (never) to three (daily) and computed a sum score rather than an averaged index $(M=2.66, S D=3.37$; possible range 0-18). Respondents' 'campaign participation,' our second dependent variable, was measured by asking whether or not $(0 / 1)$ they had, during the campaign, engaged in a number of activities (e.g., volunteered for a political party or candidate, or done an election test on the internet). The six items were combined to a sum score $(M=1.23, S D=.88)$.

Participants answered questions regarding their 'offline media' use related to politics during the last week (0-7 days; index of three media types; $M=3.05$, $S D=1.93)$, and indicated how often they encountered political issues through several 'online media' during the same time (index of three media types; $M=2.96$, $S D=1.93)$. We also take into account how often, during the preceding week, participants had encountered something 'about politics on social media' ( $M=4.57$, $S D=2.42$; range 0-7 days) and how 'interested they were in politics' ( 1 not at all-11 very interested; $M=$ $7.04, S D=2.24$ ). Importantly, these variables do not specifically relate to the election, but assess general political information and interest. Participants indicated how often they talked about politics during the weeks leading up to the election (range 1-never to 4-daily) with close friends $(M=2.81, S D=.76)$ and classmates or colleagues $(M=2.83, S D=.82)$; both items were merged to an index of 'peer political talk' $(M=2.77, S D=.76)$. In order to control for the political engagement of their classroom environment, we also asked them how many of their 'classmates or fellow students turned out to vote' in the municipality elections ( $1=$ none, $4=$ all of them; $M=2.76, S D=.63$ ). Since our data collection took place immediately after a large get-out-the-vote campaign, we asked them about the 'number of lessons' in which they talked about the local election and politics at their school or university (none, 1-2 lessons, 3-5, 5-10, $>10 ; M=2.89, S D=1.27$ ). They also indicated how often they participated in events organized by the campaign in their region (range $0-8 ; M=.96, S D=.96$ ).

\section{Results}

To answer RQ1, we regress the number of political actors respondents follow on a range of potentially relevant predictor variables $(F(10,556)=18.10, p<.001$; see Table 1). Students' political interest positively relates to the likelihood of following more politicians on social media $(\beta=.347, p<.001)$, as does increased political peer 
Table 1. Predictors of following politicians on social media.

\begin{tabular}{lcc}
\hline & Following politicians \\
\hline Gender (female) & $-.095^{*}(.071)$ & .035 \\
Age & $.024)$ \\
Political interest & $.347^{* * *}(.018)$ \\
Political news use & \\
$\quad$ On social media & $.139 * *(.017)$ \\
$\quad$ Online & .092 & $(.023)$ \\
$\quad$ Offline & -.046 & $(.022)$ \\
Turnout classmates & .029 & $(.058)$ \\
Peer political talk & $.093^{*}$ & $(.054)$ \\
Number of school lessons & .024 & $(.035)$ \\
Number of events & -.037 \\
$N$ & $(.042)$ \\
Adj. $R^{2}$ & 567 \\
\hline
\end{tabular}

Notes: Standardized beta coefficients; standard errors in parentheses. ${ }^{*} p<0.05,{ }^{* *} p<0.01,{ }^{* * *} p<0.001$.

talk with close friends and classmates $(\beta=.093, p=.039)$, and male respondents follow more political actors than females $(\beta=-.095, p=.012)$. Seeing posts about politics on social media is positively correlated with following politicians as well $(\beta=.139, p=.002)$, although the direction of this effect needs to be interpreted with caution given the cross-sectional design of the data. The strong correlation with political interest corresponds with findings from earlier work, confirming the importance of individual motivations in shaping social media selection (Thorson et al., 2019).

For our second research question, we test whether following politicians relates to the number of political posts citizens receive from: (a) political actors; (b) the news media; (c) friends and/or followers; and in the form of (d) political ads (Table 2). Following politicians is positively linked to the likelihood that young citizens encounter more political social media posts from political actors $(\beta=.178, p<.001)$, but also from friends or followers $(\beta=.130, p=.004)$. However, the number of political actors one follows plays no role in how frequently political content by news media or paid political ads are encountered. All four sources of political content are more likely to be seen by young Danes who talk to their peers about politics more often, but political interest only correlates with the amount of posts seen by politicians or parties $(\beta=.121, p=.008)$. We thus find that young citizens' social media environment is indeed shaped by the number of political actors they decide to follow, but that this influence extends beyond posts from politicians or parties and relates to an increased number of encounters with political posts by friends or followers.

In order to assess whether receiving political information from political actors positively relates to citizens' level of civic messaging and campaign participation $(\mathrm{H} 1)$, and whether both relationships are mediated by politi-

Table 2. Regression results for the likelihood to encounter political posts on social media by different sources.

\begin{tabular}{|c|c|c|c|c|c|c|c|c|}
\hline \multirow[b]{3}{*}{ Gender (female) } & \multicolumn{8}{|c|}{ Encounter social media posts about the election from different sources } \\
\hline & \multicolumn{2}{|c|}{ Political actors } & \multicolumn{2}{|c|}{ News media } & \multicolumn{2}{|c|}{ Friends/ followers } & \multicolumn{2}{|c|}{ Paid ads } \\
\hline & -.018 & $(.073)$ & -.011 & $(.070)$ & .002 & $(.077)$ & -.054 & $(.082)$ \\
\hline Age & .017 & $(.025)$ & -.024 & $(.024)$ & .024 & $(.026)$ & -.011 & $(.028)$ \\
\hline Political interest & $.121 * *$ & $(.020)$ & .053 & $(.019)$ & .001 & $(.021)$ & .058 & $(.022)$ \\
\hline \multicolumn{9}{|l|}{ Political news use } \\
\hline On social media & $.263^{* * *}$ & $(.018)$ & $.347^{*}$ & $(.017)$ & $.223 * *$ & ${ }^{*}(.019)$ & $.184^{* *}$ & $(.020)$ \\
\hline Online & .070 & $(.024)$ & .058 & $(.023)$ & .024 & $(.026)$ & $.150 * *$ & $(.027)$ \\
\hline Offline & -.001 & $(.023)$ & .057 & $(.022)$ & .046 & $(.024)$ & -.001 & $(.026)$ \\
\hline Turnout classmates & -.036 & $(.060)$ & -.069 & $(.057)$ & -.033 & $(.063)$ & -.020 & $(.067)$ \\
\hline Peer political talk & $.148 * *$ & $(.056)$ & $.111^{*}$ & $(.054)$ & $.142^{* *}$ & $(.059)$ & $.147^{* *}$ & $(.062)$ \\
\hline Number of school lessons & .073 & $(.036)$ & .091 & $(.035)$ & -.012 & $(.038)$ & .031 & $(.040)$ \\
\hline Number of events & -.017 & $(.043)$ & .008 & $(.041)$ & .008 & $(.045)$ & .020 & $(.048)$ \\
\hline Following politicians & $.178 * * *$ & $(.044)$ & .035 & $(.042)$ & $.130 * *$ & $(.046)$ & .048 & $(.049)$ \\
\hline$N$ & \multicolumn{2}{|c|}{567} & \multicolumn{2}{|c|}{567} & \multicolumn{2}{|c|}{567} & \multicolumn{2}{|c|}{567} \\
\hline Adj. $R^{2}$ & \multicolumn{2}{|c|}{.294} & \multicolumn{2}{|c|}{.266} & \multicolumn{2}{|c|}{.138} & \multicolumn{2}{|c|}{.170} \\
\hline
\end{tabular}

Notes: Standardized beta coefficients; standard errors in parentheses. ${ }^{*} p<0.05,{ }^{* *} p<0.01,{ }^{* * *} p<0.001$. 
Table 3. Results of two mediation analyses on the influence of following politicians through a heightened exposure to political posts by parties and politicians and friends/followers.

\begin{tabular}{|c|c|c|}
\hline & Civic messaging & Campaign participation \\
\hline Following politicians & $1.098 * * *(.150)$ & $.193 * * *(.041)$ \\
\hline Gender (female) & $-.204 \quad(.247)$ & $-.003 \quad(.067)$ \\
\hline Age & -.011 & $.041 \quad(.023)$ \\
\hline Political interest & $(.068)$ & $.076 * * *(.018)$ \\
\hline \multicolumn{3}{|l|}{ Political news use } \\
\hline On social media & $(.063)$ & -.015 \\
\hline Online & $(.082)$ & $(.022)$ \\
\hline Offline & $(.078)$ & $(.021)$ \\
\hline Turnout classmates & $(.201)$ & $(.054)$ \\
\hline Peer political talk & $(.190)$ & $(.052)$ \\
\hline Number of school lessons & $(.122)$ & $.087 * * \quad(.033)$ \\
\hline Number of events & $(.145)$ & $-.014 \quad(.039)$ \\
\hline \multicolumn{3}{|c|}{ Mediators: Encounter social media posts from } \\
\hline Political actors & $-.040 \quad(.153)$ & $(.041)$ \\
\hline Friends/followers & $.985 * * *(.145)$ & $(.039)$ \\
\hline$N$ & 567 & 567 \\
\hline$R^{2}$ & .325 & .254 \\
\hline
\end{tabular}

Notes: Unstandardized coefficients; standard errors in parentheses. ${ }^{*} p<0.05,{ }^{* *} p<0.01,{ }^{* * *} p<0.001$.

cal content from different sources encountered on social media (RQ3), we run two mediation analyses using PROCESS (Hayes, 2013; Table 3). Following politicians is the main predictor, and we consider the amount of political posts encountered by political actors and friends/followers as mediators, since they significantly relate to the predictor in the previous analysis. All other variables are included as controls. Both participation $(b=1.098, p<.001)$ and civic messaging $(b=.193$, $p<.001)$ correlate with the number of political actors young citizens follow on social media (i.e., the direct effect), which confirms $\mathrm{H} 1$.

Political interest $(b=.076, p<.001)$ and the number of school lessons about the upcoming election $(b=.087$, $p=.009$ ) are only directly related to campaign participation. For civic messaging, the total effect of following politicians through the amount of posts seen by both political actors and friends/followers is positive and significant ( $b=.124,95 \%$ bootstrap $\mathrm{Cl}[.028, .229])$, but the indirect effect is only significant through friends' posts. Similarly, campaign participation increases if young citizens follow more political actors on social media and, consequently, encounter more political posts from both sources $(b=.018, \mathrm{Cl}[.003, .036])$, but only friends and followers' political posts matter significantly. We thus answer RQ3 by stating that it is only encounters with political posts from friends and followers that mediate the relationship between following politicians and both campaign participation and civic messaging.

\section{Discussion}

While a growing body of research investigates why and how politicians engage on social media, we know little about the effects of these representations for users' political attitudes and behavior-especially among the age group most attuned to communication through social media. In our study, $46.9 \%$ of young Danes between the ages of 15 and 25 follow at least one politician or party on social media: Actively curating politicians into one's personal news feed appears an accepted mode of seeking out political information for young citizens. We observe notable differences between adolescents who click the 'like' button and those who do not. In line with research on other forms of engagement (Lee et al., 2013), we find that political interest and peer talk are associated with a higher chance of following politicians. In this early stage of life, political interest-often described as a personal trait and therefore an individual characteristic (see Moeller, Shehata, \& Kruikemeier, 2018)-already shapes citizens' political information environment. When this trait differentiates further in life, the active selection of political actors in citizens' social media news diet may evolve further. Importantly, political interest is not the sole defining prerequisite for young Danes' engagement with political content, nor do we argue that those youths with a comparably lower level of political interest are necessarily at a disadvantage in the socialization process. Findings by Bene (2017) show that young citizens who share and post political content on Facebook have a high level of political interest, but others still passively consume political information shared by their peers and are likely to profit from this curation decision. In addition, we assume a difference between selection effects (the choice to follow politicians on social media during formative years) and media effects (exposure to content provided by politicians). For the former, we document a significant (albeit not necessarily causal) relationship, and 
we believe that the type of content shared on social media due to its characteristics of interactivity, personalization, and brevity (Kruikemeier, van Noort, Vliegenthart, \& de Vreese, 2013) might be at least as effective for young audiences characterized by low political interest. In line with research into the capacity of soft news to convey political information to a less politically interested audience (e.g., Baum \& Jamison, 2006), we assume that social media content from political actors can lead to an increase in political learning. On a social level, we expect that the presence and visibility of political actors in the social network might lead to a closer relationship with politics in general.

Another important indicator for following politicians in our data is peer talk within young citizens' social networks at school or university, potentially due to the function of social recommendations. This speaks to the mutual influence of self-selecting into peer networks that provide a political-information-rich social media diet and engagement with political content, shaping citizenoriented identity formation. We also find that following politicians plays a role in young citizens' social media diet. This may seem a tautological finding at first sight, but is not. Even though followers of politicians see more political posts, they do not receive them through the news media but rather through peers and political actors. This means we document a process of de-mediation of politics on social media: Legacy media lose influence as primary information sources and are replaced by direct communication with political actors who can share their information without journalistic interference. This finding is in line with recent advances in the study of populist communication styles, where political actors circumvent the filter of established media (e.g., Engesser, Ernst, Esser, \& Büchel, 2017). This limits journalistic possibilities of maintaining a gatekeeping function for young voters and raises concerns about manipulation and misinformation. However, our findings also indicate that young voters seek out a more immediate relation with politics (Manning et al., 2017), in line with a normative direct democratic ideal. Importantly, while following political actors can be the first step in a process of direct communication where politicians and citizens enter into a constructive dialogue, a 'like' is not a sufficient condition for user engagement (Heiss, Schmuck, \& Matthes, 2019).

Our results show that when it comes to young citizens' campaign participation and civic messaging, the source of political information posts on social media makes a difference. Tested individually, we find that posts by politicians and friends lead to greater campaign engagement; when tested simultaneously, only information by friends and followers remain a significant factor of both types of campaign engagement. This is a strong indication of a networked communication logic, where personal interests and peer networks shape the information experienced online. We cannot make inferences about youths' motivations for sharing content online, but previous works highlights the importance of individual considerations when assessing information, its 'repacking' before sharing, and the role the anticipated audience plays in this regard (Park \& Kaye, 2019). Interviews with young American citizens (Thorson, 2014) show that some youths are 'social politics curators,' who are greatly engaged in politics and post or share a large number of political messages on social media. Youths further rely on trusted friends to curate their news content and 'filter' important information from the mainstream media for them (Vromen, Xenos, \& Loader, 2014). These findings highlight the role of peer curators of political content in the process of news diffusion and distribution among young citizens; this influence may be attributable to heightened credibility perceptions and the content's presumed utility. If information is received via a (personally) known source such as a friend, it is more likely to catch one's attention and be considered more relevant and decisive for behaviour (e.g., Kaiser et al., 2018). These considerations raise further questions regarding the veracity of online information: If friends' recommendations serve as heuristic cues for social media users' assessment of a story's credibility, this may increase the likelihood that false information is spread through social networks. Educational efforts in media literacy may be a promising tool in this regard, particularly if they allow adolescents to develop critical evaluation (e.g., Leeder, 2019).

Furthermore, if citizens follow specific politicians, this may also increase the likelihood that posts and recommendations from peers with a similar political orientation become prioritized in the news feed, strengthening users' political self and positively affecting participatory outcomes. In contrast, a possible reason for the lack of influence of exposure to politicians' posts on behaviors may relate to their specific content: It is feasible to assume that the posts were not (solely) designed to mobilize youth voters, but rather the electorate at large. However, we cannot testify to the content of the different messages, and hence urge further research into this field.

Lastly, we find that following politicians directly relates to campaign engagement. Additional factors may exist that mediate the relationship between following politicians and our dependent variables that we did not account for (Zhao, Lynch, \& Chen, 2010). For example, by following politicians, young citizens not only receive more political information on social media, but also become more attentive to such topics in the offline environment. Another explanation may be an increase in interpersonal political discussion offline that leads to heightened political participation, and/or heightened feelings of political efficacy. The fact that we still observe a direct effect irrespective of the significant indirect relationship can indicate that following politicians in and by itself affects civic messaging and campaign participation. We do not know which types of political actor young citizens in our sample followed, which makes it difficult to speculate about their influence. Our data show that the 
quantity of politicians one engages with on social media matter for political behaviour, but the quality of these follower-relationships may be just as important.

This study has several limitations. The cross-sectional nature of our data warrants caution in causal interpretation, and we refrained from testing a serial mediation model. Furthermore, while we initially measured citizens' political efficacy, the scale failed to reach sufficient reliability and we excluded it from further analyses. Importantly, it has not been our goal to investigate the relationship between social media use and young citizens' political efficacy, nor do we want to suggest a specific order in which different types of behaviors are influenced. Rather, we add an understudied factor (i.e., following politicians) to the well-established process from personal predispositions over exposure to political behavior (such as suggested, e.g., in the O-S-R-O-R framework; Park \& Kaye, 2019). The data for this study were collected in the context of an ongoing get-out-the-vote campaign, making it hard to disentangle campaign effects from the impact of citizens' day-to-day political information diet. While we differentiate between factors relating to election-specific activities and general forms of engagement, our concepts are inherently related; future work should thus aim at establishing causality for these assumptions. Furthermore, we cannot provide information about the content of the political posts young people encountered on social media, and do not know whether these were consistent with their own attitudes. The extent to which citizens are exposed to cross-cutting information, particularly through recommendations on social media platforms, may have important consequences for political behavior (e.g., Messing \& Westwood, 2014).

Finally, future work should distinguish between different social media platforms in order to understand whether the interdependence of individual choices and algorithmic curation varies, and how far the relationships investigated here may be more (or less) pronounced depending on specific platforms in line with their affordances (e.g., Kalsnes, Larsson, \& Enli, 2017; Ohme et al., 2019).

Our study is part of a recent endeavor that investigates results of content curation and the interplay of different political news sources on social media (e.g., Thorson et al., 2019). Following political actors can be a catalyst for young people's exposure to campaign news; however, their friends and followers function as the main node in their online networks. This interplay likely means that younger generations will be informed about politics in a more selective way that is driven by individual characteristics and social status and thereby supports the 'richget-richer' paradigm (Shehata \& Strömbäck, 2018). Yet the relationship between active curation and the passive selection mechanism functions as a driver of campaign behavior. The networked communication logic, hence, seems to alter young people's media diet, but also presents opportunities to mobilize the youth.

\section{Acknowledgments}

The authors wish to thank Aslak Gottlieb for his continued support during the project. Part of the research time for this study was supported by a research grant from the European Research Council (grant No. 647316).

\section{Conflict of Interests}

The authors declare no conflict of interests.

\section{References}

Aalberg, T., \& Jenssen, A. T. (2007). Do television debates in multiparty systems affect viewers? A quasiexperimental study with first-time voters. Scandinavian Political Studies, 30(1), 115-135.

Banaji, S., \& Buckingham, D. (2010). Young people, the Internet, and civic participation: An overview of key findings from the CivicWeb project. International Journal of Learning and Media, 2(1), 15-24.

Baum, M. A., \& Jamison, A. S. (2006). The Oprah effect: How soft news helps inattentive citizens vote consistently. The Journal of Politics, 68(4), 946-959.

Bene, M. (2017). Influenced by peers: Facebook as an information source for young people. Social Media + Society, 3(2). https://doi.org/10.1177/205630 5117716273

Bennett, W. L. (2008). Changing citizenship in the digital age. In W. L. Bennett (Ed.), Civic life online: Learning how digital media can engage youth (pp. 1-24). Cambridge, MA: MIT Press.

Coleman, S. (2008). Doing IT for themselves: Management versus autonomy in youth e-citizenship. In W. L. Bennett (Ed.), Civic life online: Learning how digital media can engage youth (pp. 189-206). Cambridge, MA: MIT Press.

Craig, S. C., Niemi, R. G., \& Silver, G. E. (1990). Political efficacy and trust: A report on the NES pilot study items. Political Behavior, 12(3), 289-314.

Engesser, S., Ernst, N., Esser, F., \& Büchel, F. (2017). Populism and social media: How politicians spread a fragmented ideology. Information, Communication \& Society, 20(8), 1109-1126.

Enli, G. S., \& Rosenberg, L. T. (2018). Trust in the age of social media: Populist politicians seem more authentic. Social Media + Society, 4(1). https://doi.org/ $10.1177 / 2056305118764430$

Enli, G. S., \& Skogerb $\varnothing$, E. (2013). Personalized campaigns in party-centred politics. Information, Communication \& Society, 16(5), 757-774.

Fisher, C., Culloty, E., Lee, J. Y., \& Park, S. (2019). Regaining control: Citizens who follow politicians on social media and their perceptions of journalism. Digital Journalism, 7(2), 230-250.

Geber, S., \& Scherer, H. (2015). My voter, my party, and me: American and German parliamentarians on Face- 
book. Journal of Information Technology \& Politics, 12(4), 360-377.

Gerber, A. S., Green, D. P., \& Shachar, R. (2003). Voting may habit-forming: Evidence from a randomized field experiment. American Journal of Political Science, 47(3), 540-550.

Hayes, A. F. (2013). Introduction to mediation, moderation, and conditional process analysis: A regressionbased approach. New York, NY: Guilford Press.

Heiss, R., Schmuck, D., \& Matthes, J. (2019). What drives interaction in political actors' Facebook posts? Profile and content predictors of user engagement and political actors' reactions. Information, Communication \& Society, 22(10), 1497-1513.

Kahne, J., Lee, N.-J., \& Feezell, J. T. (2013). The civic and political significance of online participatory cultures among youth transitioning to adulthood. Journal of Information Technology \& Politics, 10(1), 1-20.

Kaiser, J., Keller, T. R., \& Kleinen-von Königslöw, K. (2018). Incidental news exposure on Facebook as a social experience: the influence of recommender and media cues on news selection. Communication Research. Advance online publication. https://doi.org/ 10.1177\%2F0093650218803529

Kalsnes, B., Larsson, A. O., \& Enli, G. (2017). The social media logic of political interaction: Exploring citizens' and politicians' relationship on Facebook and Twitter. First Monday, 22(2). https://doi.org/10.5210/fm. v22i2.6348

Karlsen, R. (2015). Followers are opinion leaders: The role of people in the flow of political communication on and beyond social networking sites. European Journal of Communication, 30(3), 301-318.

Keller, T. R., \& Kleinen-von Königslöw, K. (2018). Followers, spread the message! Predicting the success of Swiss politicians on Facebook and Twitter. Social Media + Society, 4(1). https://doi.org/10.1177/ 2056305118765733

Kreiss, D., Lawrence, R. G., \& McGregor, S. C. (2018). In their own words: Political practitioner accounts of candidates, audiences, affordances, genres, and timing in strategic social media use. Political Communication, 35(1), 8-31.

Kristensen, J. B., Albrechtsen, T., Dahl-Nielsen, E., Jensen, M., Skovrind, M., \& Bornakke, T. (2017). Parsimonious data: How a single Facebook like predicts voting behavior in multiparty systems. PLOS One, 12(9). https://doi.org/10.1371/journal.pone.0184562

Kruikemeier, S., van Noort, G., Vliegenthart, R., \& de Vreese, C. H. (2013). Getting closer: The effects of personalized and interactive online political communication. European Journal of Communication, 28(1), 53-66.

Lee, N. J., Shah, D. V., \& McLeod, J. M. (2013). Processes of political socialization: A communication mediation approach to youth civic engagement. Communication Research, 40(5), 669-697.

Leeder, C. (2019). How college students evaluate and share "fake news" stories. Library \& Information Science Research, 41(3). https://doi.org/10.1016/j.lisr. 2019.100967

Literat, I., Kligler-Vilenchik, N., Brough, M., \& Blum-Ross, A. (2018). Analyzing youth digital participation: Aims, actors, contexts and intensities. The Information Society, 34(4), 261-273.

Loader, B. D. (Ed.). (2007). Young citizens in the digital age: Political engagement, young people and new media. Abingdon: Routledge.

Mannheim, K. (1952). The problem of generations. London: Routledge and Kegan Paul. (Original work published 1928)

Manning, N., Pennfold-Mounce, R., Loader, B. D., Vromen, A., \& Xenos, M. (2017). Politicians, celebrities and social media: a case of informalisation? Journal of Youth Studies, 20(2), 127-144.

Matsa, K. E., Silver, L., Shearer, E., \& Walker, M. (2018). Younger Europeans are far more likely to get news from social media. Pew Research Centre. Retrieved from https://www.journalism.org/2018/10/30/ younger-europeans-are-far-more-likely-to-getnews-from-social-media

Maurissen, L. (2018). Political efficacy and interest as mediators of expected political participation among Belgian adolescents. Applied Developmental Science. Advance online publication. https://doi.org/10.1080/ 10888691.2018.1507744

Messing, S., \& Westwood, S. J. (2014). Selective exposure in the age of social media: Endorsements trump partisan source affiliation when selecting news online. Communication Research, 41(8), 1042-1063.

Moeller, J., de Vreese, C., Esser, F., \& Kunz, R. (2014). Pathway to political participation: The influence of online and offline news media on internal efficacy and turnout of first-time voters. American Behavioral Scientist, 58(5), 689-700.

Moeller, J., Shehata, A., \& Kruikemeier, S. (2018). Internet use and political interest: Growth curves, reinforcing spirals, and causal effects during adolescence. Journal of Communication, 68(6), 1052-1078.

Nielsen, R. K., \& Vaccari, C. (2013). Do people 'like' politicians on Facebook? Not really. Large-scale direct candidate-to-voter online communication as an outlier phenomenon. International Journal of Communication, 7, 2333-2356.

Ohme, J. (2019). When digital natives enter the electorate: Political social media use among first-time voters and its effects on campaign participation. Journal of Information Technology \& Politics, 16(2), 119-136.

Ohme, J., de Vreese, C. H., \& Albæk, E. (2018). The uncertain first-time voter: Effects of political media exposure on young citizens' formation of vote choice in a digital media environment. New Media \& Society, 20(9), 3243-3265.

Ohme, J., Marquart, F., \& Kristensen, L. M. (2019). School lessons, social media and political events in a getout-the-vote campaign: Successful drivers of polit- 
ical engagement among youth? Journal of Youth Studies. Advance online publication. https://doi.org/ 10.1080/13676261.2019.1645311

Park, C. S., \& Kaye, B. K. (2019). Mediating roles of news curation and news elaboration in the relationship between social media use for news and political knowledge. Journal of Broadcasting \& Electronic Media, 63(3), 455-473.

Parmelee, J. H., \& Roman, N. (2019). Insta-politicos: Motivations for following political leaders on Instagram. Social Media \& Society, 5(2). https://doi.org/ $10.1177 / 2056305119837662$

Reuters (2019). Reuters digital news report 2019. Oxford: Reuters Institute. Retrieved from https:// reutersinstitute.politics.ox.ac.uk/sites/default/files/ inline-files/DNR_2019_FINAL.pdf

Rossi, L., Schwartz, S., \& Mahnke, M. (2016). Social media usage Denmark 2016. Copenhagen: IT University Copenhagen. Retrieved from https://blogit. itu.dk/decidis/wp-content/uploads/sites/5/2016/ 03/Decidis_report_2016.pdf

Sahly, A., Shao, C., \& Kwon, K. H. (2019). Social media for political campaigns: An examination of Trump's and Clinton's frame building and its effects on audience engagement. Social Media + Society, 5(1). https:// doi.org/10.1177/2056305119855141

Sanders, M. S. (2001). Uncertainty and turnout. Political Analysis, 9(1), 45-57.

Shehata, A., \& Strömbäck, J. (2018). Learning political news from social media: Network media logic and current affairs news learning in a high-choice media environment. Communication Research. Advance online publication. https://doi.org/10.1177/ 0093650217749354

Skovsgaard, M., \& van Dalen, A. (2013). Dodging the gatekeepers? Social media in the campaign mix during the 2011 Danish elections. Information, Communication \& Society, 16(5), 737-756.

Stier, S., Bleier, A., Lietz, H., \& Strohmaier, M. (2018). Election campaigning on social media: Politicians, audi- ences, and the mediation of political communication on Facebook and Twitter. Political Communication, 35(1), 50-74.

Thorson, K. (2014). Facing an uncertain reception: Young citizens and political interaction on Facebook. Information, Communication \& Society, 17(2), 203-216.

Thorson, K., Cotter, K., Medeiros, M., \& Pak, C. (2019). Algorithmic inference, political interest, and exposure to news and politics on Facebook. Information, Communication \& Society. Advance online publication. https://doi.org/10.1080/1369118X.2019.1642934

Thorson, K., \& Wells, C. (2016). Curated flows: A framework for mapping media exposure in the digital age. Communication Theory, 26(3), 309-328.

Valentino, N. A., \& Sears, D. O. (1998). Event-driven political communication and the preadult socialization of partisanship. Political Behavior, 20(2), 127-154.

van Dalen, A., Fazekas, Z., Klemmensen, R., \& Hansen, K. M. (2015). Policy considerations on Facebook: agendas, coherence, and communication patterns in the 2011 Danish Parliamentary elections. Journal of Information Technology \& Politics, 12(3), 303-324.

Vromen, A., Xenos, M. A., \& Loader, B. (2014). Young people, social media and connective action: From organisational maintenance to everyday political talk. Journal of Youth Studies, 18(1), 80-100.

Weeks, B. E., Kim, D. H., Hahn, L. B., Diehl, T. H., \& Kwak, N. (2019). Hostile media perceptions in the age of social media: Following politicians, emotions, and perceptions of media bias. Journal of Broadcasting \& Electronic Media, 63(3), 374-392.

Wicks, R. H., \& Drew, D. G. (1991). Learning from news: Effects of message consistency and medium on recall and inference making. Journalism Quarterly, 68(1/2), 155-164.

Zhao, X., Lynch, J. G., Jr., \& Chen, Q. (2010). Reconsidering Baron and Kenny: Myths and truths about mediation analysis. Journal of Consumer Research, 37(2), 197-206.

\section{About the Authors}

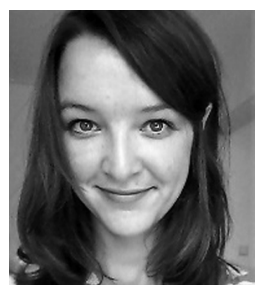

Franziska Marquart is a Postdoctoral Researcher at the Center for Politics and Communication at the Amsterdam School of Communication Research. She is part of the ERC-funded project Europinions, which investigates the antecedents and consequences of public opinion towards the European Union. She earned her PhD (2015) from the University of Vienna in Austria, studying the content and effects of right-wing populist political advertisements. Her research focuses on political communication effects and experimental methods.

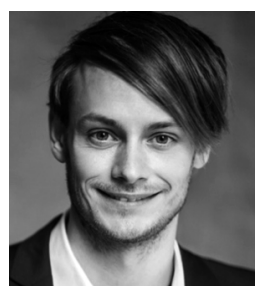

Jakob Ohme is a Postdoctoral Researcher in the Digital Communication Methods Lab at the Amsterdam School of Communication Research, University of Amsterdam. His research interests center on political communication effects, the impact of digital media on political behavior and attitudes, and the development of new methodological approaches in political communication research. As part of the Digital Communication Methods Lab, Jakob investigates effects of mobile media exposure by employing mobile methods, such as mobile data donations, mobile eye-tracking, and the use of specific survey apps. He earned his PhD (2017) from the Centre for Journalism at the University of Southern Denmark. 


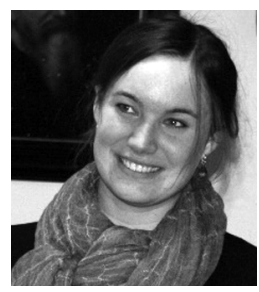

Judith Möller is a Tenured Assistant Professor for Political Communication at the Department of Communication Science at the University of Amsterdam. She is affiliated with the Amsterdam School of Communication Research, the Center for Politics and Communication, and the Information, Communication, \& the Data Society Initiative. In her research, she focuses on the effects of political communication, in particular social and digital media. She is fascinated by the complex relationship between expressions of citizenship and communication characterized by intertwined causal links and conditioned by the political system. 